\title{
DEKONSTRUKSI DAN REKONSTRUKSI TERHADAP PENDIDIKAN KARAKTER DI MASA PANDEMI COVID 19: Strategi Pembelajaran Mata Kuliah Muamalat
}

\author{
Amir Bandar Abdul Majid \\ Universitas Islam Negeri Sunan Kalijaga Yogyakarta \\ E-mail:19204010123@student.uin-suka.ac.id
}

\begin{tabular}{|c|c|c|}
\hline Received & Revised & Accepted \\
\hline 10 Januari 2021 & 10 Februari 2021 & 28 Maret 2021 \\
\hline
\end{tabular}

\section{DECONSTRUCTION AND RECONSTRUCTION TO CHARACTER EDUCATION DURING COVID-19 PANDEMIC: A LEARNING STRATEGY AT MUAMALAH SUBJECT}

\begin{abstract}
The purpose of this study is to find a learning model that can make students active and communicative in online lessons during pandemics like this. The learning model is deconstruction and reconstruction learning. This research is qualitative research that uses a descriptive approach. The form of data presentation is taken from students of the study program muamalah faculty of sharia and Islamic law Sunan Kalijaga State Islamic University Yogyakarta from Grades A, B, and C. The results obtained from this study is with the model of deconstruction and reconstruction learning that can make active learning in the sense that many students respond to the material in different points of view. The learning model can also make lecturers and students more communicative to each other.

Keywords: deconstruction, reconstruction, process, material, and character education.

Abstrak

Tujuan penelitian ini untuk menemukan model pembelajaran yang dapat menjadikan mahasiswa aktif dan komunikatif dalam pelajaran daring di masa pandemi seperti ini. Model pembelajaran tersebut adalah pembelajaran dekonstruksi dan rekonstruksi. Penelitian ini merupakan penelitian kualitatif yang menggunakan pendekatan dekriptif. Bentuk penyajian data diambil dari mahasiswa prodi muamalah fakultas syariah dan hukum islam Universitas Islam Negeri Sunan Kalijaga Yogyakarta dari Kelas A, B, dan C. Hasil yang didapatkan dari penelitian ini adalah dengan model pembelajaran dekonstruksi dan rekonstruksi bahwa dapat menjadikan pembelajaran yang aktif dalam artian banyak mahasiswa yang menanggapi materi dalam sudut pandang yang berbeda. Model pembelajaran tersebut juga dapat menjadikan dosen dan mahasiswa lebih komunikatif untuk saling betanya.
\end{abstract}

Kata kunci: dekonstruksi, rekonstruksi, proses, materi, dan pendidikan karakter. 


\section{Pendahuluan}

Pendidikan di masa pandemi dengan pendidikan keadaan normal sangat berbeda. Karena selama masa pandemi pembelajaran yang dilakukan berbasis online sementara dalam keadaan normal bisa dilakukan dengan tatap muka. Proses pendidikan sangat menentukan keberhasilan pembelajaran seperti yang tercantum dalam kurikulum 13 latar belakang filosofis sub "b" bahwa dikatakan suatu proses pendidikan adalah mampu menjadikan peserta didik yang berpikir rasional dan cemerlang. Sedangkan pandemi ini yang tidak terlepas dengan ruang dan waktu sangat mempengaruhi sistem belajar peserta didik baik pengetahuan, kedisiplian, dan ketertiban. Van Baal juga mengatakan bahwa manusia akan mendapatkan sesuatu yang baru didapatkan dengan dua cara yaitu: belajar dan totalitas. ${ }^{1}$ Oleh karenanya dalam pendidikan sangat perlu yang namanya belajar yang sungguhsungguh dan menjalankan semua tahapannya.

Sistem pendidikan yang diterapkan di masa pandemi ini lebih cenderung satu arah. Alasannya yaitu banyak peserta didik baik pelajar dan mahasiswa mematikan kameranya ketika ngezoom, G-meet, sampek kepada tugas sendiripun tidak dikerjakan oleh dirinya sendiri. Peristiwa seperti ini maka perlu menggunakan strategi pembelajaran yang tepat untuk peserta didik supaya nilai pendidikan (ilmu) itu sampai kepada peserta didik. Seperti halnya yang diungkapkamn oleh Johnson: ${ }^{2}$

"jika guru ahli mengelola dengan bakat kreatif dan

kemampuan mengajar murid-murid di semua level, maka bisa jadi

anda tidak mempunyai kesulitan dalam menjalakan seluruh

kurikulum yang diissyaratkan bagi mata pelajaran atau kelas"

Hal ini menunjukan bahwa perlu adanya strategi yang baik dalam mengatur kelas dan pembelajaran. Sehingga dalam kondisi apapun pembelajaran tetap dilaksanakan dengan yang baik. Ketidak ikut sertaan peserta didik dalam mengaktifkan kamera, tertib dan disiplin seperti halnya tepat waktu dan harus standby di layar komputer tidak bisa kita paksakan. Menjadi konsekuensi logis ketika peserta didik berada di rumah harus mengikuti pelajaran dan disisi lain statusnya sebagai anak harus berbakti kepada orang tua dan statusnya sebagai masyarakat maka ikut serta dalam kegiatan sosial. Namun tidak mengurangi substansi pendidikan itu sendiri dimana siswa tetap berpikir dimanapun dan dalam kondisi apapun. Sehingga peserta didik mendapatka ilmu dari pembeljaran tersebut. dalam buku tentang pembelajaran aktif yang diungkapkan oleh Hisyam Zaini,"pada materi yang sama jika dijelaskan atau disampaikan oleh guru yang berbeda maka hasil penerimaan siswapun juga berbeda". ${ }^{3}$ Dalam hal ini strategi atau metode memiliki pengaruh besar dalam proses pendidikan.

Menurut Wina Sanjaya, strategi dan metode sangat menentukan dalam keberhasilan pendidikan. ${ }^{4}$ Dalam pendidikan itu sendiri walaupun tidak dalam

1 J.Van Baal, Sejarah dan Pertumbuhan Teori antropologi Budaya, jilid 2 pengantar Selo Soemardjan, hal. 70-71

${ }^{2}$ Louarne Johnson, Pengajaran yang Kreatif, (Indeks, 2008), hal. 45

${ }^{3}$ Hisyam Zaini dkk, Strategi Pembelajaran Aktif, (Yogyakarta:Pustaka Insani Madani, 2008), hal. 13.

2010) Hal.60

${ }^{4}$ Wina Sanjaya. Strategi Pembelajaran Berorientasi Standart Proses Pendidikan.(Jakarta:Prenada. 
kondisi pandemi seperti ini guru sudah seharusnya dan wajib memiliki metode dan strategi untuk mendapatkan hasil yang baik pula. Masa pandemi seperti ini proses pembelajaran atau sistem pendidikan lebih luwes dan tidak boleh kaku. Dalam artian pendidikan yang tadinya harus menggunakan seragam dan pakaian rapi namun ketika online harus lebih mementingkan substansi pendidikan istu sendiri dibandigkan kegiatan yang hanya berbentuk formal saja. Peristiwa seperti ini dikatakan dekonstruksi epistemologi pendidikan seperti yang dijelaskan oleh Syafi'i Ma'arif yang dikutip oleh Muslih Usa dan Aden Wijaya, "Pendidikan islam sekarang menganut sistem pendidikan warisan abad pertengahan bagian akhir". ${ }^{5}$ Saat ini abad pertengahan akhir barat sudah bisa mengakses pendidikan tanpa ruang dan waktu, sehingga pendidikan itu bisa dilakukan kapan saja yang apada intinya substansi dari pendidikan yang berupa ilmu pengetahuan itu sampai kepada peserta didik. Selain dekonstruksi sebagai solusi epistemologi pendidikan, dekonstruksi juga masuk kepada strategi pembelajaran yakni memadukan antara nilai-nilai agama dan sains, memadukan antara kebiasaan barat dan kebiasaan saat ini selama tidak bertentangan.

Pendidikan setelah didekosntruksi baik secara proses dan isi, maka perlu yang namanya rekonstruksi pendidikan. Sehingga peserta didik tidak rancuh atau mengambang dalam memahami isi materi. Nama lain dari kegiatan seperti ini masih mempertahankan pendidikan karakter. Pendidikan karakter menurut Kirschenbaum adalah pendidikan nilai yang melibatkan pengetahuan, perasaan dan tindakan. ${ }^{6}$ Pendidikan karakter yang selalu dicangangkang untuk pendidikan indonesia bagaimanapun model dan metodenya penanaman karakter harus ada. Menghadapi persoalan tersebut bahwa pendidikan tidak boleh lepas dengan tiga aspek tersebut, yaitu pengetahuan, perasaan dan tindakan. Frankena dalam jurnal pembelajaran nilai karakter karya Adisusilo mengemukakan tujuan pendidikan itu mencakup tingkah laku, meningkatkan kemampuan secara otonom, menginternaliasikan nilainilai moral, menentukan keputusan sesuai nilai universal, dan bijaksana. ${ }^{7}$

Akibat model dekonstruksi yaitu memecah pemikiran dari isi materi tersebut, oleh karenanya harus dibangun pemahaman yang positif supaya pembelajaran itu sampai kepada tujuan pendidikan. Seperti yang dijelaskan oleh Amin Abdullah, "pembelajaran agama yang dilakukan sampai sekarang lebih banyak terfokus kepada hal-hal yang bersifat teoritis atau kognitif. Sehingga perlu ada tindakan setelah seseorang mendapatkan pendidikan mengaplikasikan dalam nilai-nilai kehidupan. ${ }^{8}$ Inilah yang dinamakan rekonstruksi pendidikan baik secara isi dan metode. Sehingga tadinya pendidikan yang diskonstruksi (pecah pemikiran) kemudian

\footnotetext{
${ }^{5}$ Muslih Usa dan Aden Wijaya, Pendidikan Islam dalam Peradaban Industrial (Yogyakarta: Aditia Media, 1987), hlm. 6

${ }^{6}$ Kirschenbaum, Howard. From Va-lues Clarification to Character Educa-tion: A Personal Journey." The Journal of Humanistic Counseling, Education and Development. Vol. 39, No. 1, September 2000.", pp. 4-20.

Adisusilo, J.R.S. Pembelajaran Nilai Ka-rakter. Jakarta: PT. Raja Grafindo Persada, 2012.

8 Amin Abdullah, "Problem Epistemologis-Metodologis Pendidikan Agama", dalam Munir Mulkhan, dkk, Relpnstruksi Pendidikan dan Tradisi Pesantren, Religiusitas Iptek, (Yogyakarta: Pustaka Pelajar, 2001), Hal 59.
} 
direkonstruksi (dibangun secara positif) dan pada akhirnya peserta didik akan menemukan pemahaman yang secara mendalam.

Dalam penerapannya pula pendidikan dekonstruksi-rekonstruksi pendidikan bisa dilakukan secara luwes dan fleksibel, dengan menekankan bahwa peserta didik tersebut paham apa yang disampaikan atau dipelajari selama ini. Penulis sebagai peneliti dan sekaligus pelaku dalam pendidikan dalam program field study yang diselenggarakan di fakultas syari'ah dan hukum islam UIN Sunan Kalijaga Yogyakarta. Maka akan meneliti terkait model dekonstruksi dan rekonstruksi dalam pendidikan. Sehingga tulisan ini akan disajikan baik secara teoritis dan data lapangan. Sehingga bisa bermanfaat untuk peneliti selanjutnya yang masih dalam satu bidag dan bermanfaat juga untuk aktivis pendidikan.

\section{Metode}

Untuk mendapatkan data yang relevan dengan permasalahan yang diangkat dalam penelitian ini, maka penulis mengumpulkan data dengan menggunakan metode observasi dan wawancara. Kemudian data diolah dengan reduksi data, analisis data dan penarikan kesimpulan. Observasi merupakan teknik pengumpulan data dengan mengadakan pengamatan terhadap kegiatan yang sedang berlangsung. ${ }^{9}$ Metode observasi untuk mengamati kondisi kelas dan proses pendidikan saat berlangsung.

Sedangkan metode wawancara adalah pertemuan dua orang untuk bertukar informasi dan ide melalui tanya jawab, sehingga dapat dikonstruksikan makna dalam suatu topik. Melalui wawancara peneliti mengetahui hal-hal yang lebih mendalam tentang partisipan dalam menginterpretasikan situasi dan kondisi yang terjadi, dimana hal ini tidak ditemukan melalui observasi. ${ }^{10}$ Wawancara dilakukan untuk mengetahui lebih dalam dengan data-data yang diambil dalam rangka menguatkan data sebelumnya serta menemukan data yang baru ketika di metode sebelumnya tidak didapatkan.

\section{Hasil dan Pembahasan}

Menurut Azyumardi Azra, bahwa pendidikan saat ini mengalami krisis metodologi dan krisis pedagogik." Krisis metodologi berkaitan dengan metode, teknik dan strategi pendidik menyampaikan ilmu kepada peserta didik. Sementara krisis pedagogik meliputi hal-hal yang berkaitan dengan pengetahuan ataus substansi pendidikan itu dipahami secara mendalam dari tingkatan yang sudah dicapai. Alasan strategi menjadi salah satu penentu keberhasilan pendidikan yaitu: 1) pengidentifikasian masalah yang menjadi sasaran utama dan harus diselesaikan; 2) pertimbangan yang ampuh untuk mencapai sasaran; 3) penetapan langkah langkah yang ditempuh sejak awal sampai akhir; 4) penetapan tolok ukur keberhasilan. ${ }^{12}$ hlm. 220 .

${ }^{9}$ Nana Syaodih Sukmadinata, Metode Penelitian Pendidikan, (Bandung: Remaja Rosdakarya, 2013),

10 Sugiyono, Metode Penelitian Pendidikan (Pendekatan Kuantitatif, Kualitatif, dan R\&D), (Bandung: Alfabeta, 2013), hlm. 317-318.

${ }_{11}$ Azyumardi Azra, "Rekonstruksi Kritis Imu dan Pendidikan Islam",hal 84-86.

12

${ }^{12}$ Abu Ahmadi dan Joko Tri Prasetyo, Strategi Belajar Mengajar (Bandung: Pustaka Setia, 1997), hal 
Sehingga mnejadi penting dan wajib untuk memilih strategi yang baik. Alasannya dengan strategi yang tepat, peserta didik akan mendapatkan proses pembelajaran yang tepat pula.

Penulis akan membahas bagaimana pendidikan di masa pandemi ini dilakukan dengan model dekonstruksi-rekonstruksi dalam penerapannya. Membahas strategi artinya membhas tentang pendidikan itu baikdari akan dimulai sampai hasil finalnya seperti apa setelah diberikan pengaruh strategi tersebut. Crown dirgantoro menyebutkan pembahasan strategi meliputi: formulasi strategi, implementasi strategi dan pengendalian strategi. ${ }^{13}$ Akan tetapi penulis meringkasnya dalam bentuk penyajian data dari proses dan isi sehingga akan dikaji lebih dalam hingga pada hasil dari penerapan strategi tersebut. penulis juga sebagai pelaku pendidikan yakni mengajar kleas $\mathrm{A}, \mathrm{B}$, dan $\mathrm{C}$, materi pertama yaitu tentang akad; dan materi yang kedua tentang riba. Sehingga nanti akan dibahas dalam setiap perubahannya peserta didik setelah mendapatkan perlakuan strategi dekonstruksirekonstruksi.

\section{Dekonstruksi \\ Proses Pendidikan}

Pendidikan di masa pandemi seperti ini perlu modifikasi proses pendidikan. Dalam artian ketika pendidikan itu biasanya dilakukan secara formal dan struktural, tapi bagaimana kegiatan formal tersebut bisa didekonstruksi yang tidak harus strukturalistik dalam pendidikan sehingga tidak menghambat pendidikan di masa pandemi. Menurut aliran strukturalis manusia bukan hanya sekedar bebas, tetapi manusia itu harus terikat struktur yang ada. ${ }^{14}$ Sementara aliran dekonstruksi Derrida mengutarakan tetantang logosentrisme sehingga membebaskan keterikatan dan tidak menjadi budak sistem. ${ }^{15}$ Seperti halnya dalam pendidikan kaum modern yang terstruktur itu bisa dilakukan dengan substansinya dan teoritiknya (dekonstruksi). Sehingga aplikasi dalam menerapkan pedidikan cenderung luwes dan tidak kaku.

Penulis melihat bahwa pola lama yang disusun oleh aktifis pendidikan seperti menggunakan seragam, kedisiplinan dan ketertiban yang bersifat kaku. Sedangkan pendidikan yang struktural di masa pandemi sperti ini dalam proses pendidikannnya harus bisa kontekstual sehingga bisa menurunkan sifat struktural tersebut pada bidang lainnya. Masih banyak sifat struktural yang lain untuk dilakukan dalam pendidikan seperti: proses pendidikan struktual terhadap langkah pembelajaran yang harus diawali salam dan seterusnya, proses pendidikan struktural yang pada kurikulum pendidikan, proses pendidikan struktural terhadap materi pembelajaran. Sehingga dalam proses pendidikan masa pandemi ini yang memang tidak sempurna terstrukur sebelum pandemi. Maka dalam memodifikasi struktual pendidikan tidak boleh kaku dan harus luwes.

13 Crown Dirgantoro, Manajemen Strategi; Konsep dan Kasus Implementasi,(Jakarta: Grafindo Persada, 2001), hal. 13-14

${ }^{14}$ Lumongga Lubis Namora,Memahami Dasar-Dasar Konseling DalamTeori DanPraktik,Jakarta: Kencana Prenada Media Grup, 2011, Hal. 50.

${ }^{15}$ George Ritzer, TeoriSosiologi Klasik Sampai Perkembangan Terakhir Postmodern, Yogyakrta: Pustaka Pelajar, 2012, Hal. 608. 
Penulis sekaligus peraktek pendidikan, dalam menerapkan pembelajaran sudah menerapkan sistem pendidikan dekosntruktif yang memformulasikan proses pendidikan yang sesuai di masa pandemi seperti ini:

Pembelajaran Materi 1:

Materi Fikih Muamalat tentang Akad pada kelas A, B, dan C

\begin{tabular}{|c|c|c|}
\hline Kelas A & Kelas B & Kelas C \\
\hline $\begin{array}{l}\text { Persiapan } \\
\text { Dalam penerapannya } \\
\text { proses pendidikan } \\
\text { dekonstruktif karena } \\
\text { cenderung lebih } \\
\text { luwes, maka pendidik } \\
\text { tidak menekankan } \\
\text { siswa harus on kamera } \\
\text { saat nge-zoom. }\end{array}$ & $\begin{array}{l}\text { Persiapan } \\
\text { Dalam penerapannya } \\
\text { proses pendidikan } \\
\text { dekonstruktif karena } \\
\text { cenderung lebih } \\
\text { luwes, maka pendidik } \\
\text { tidak menekankan } \\
\text { siswa harus on kamera } \\
\text { saat nge-zoom. }\end{array}$ & $\begin{array}{l}\text { Persiapan } \\
\text { Dalam penerapannya } \\
\text { proses pendidikan } \\
\text { dekonstruktif karena } \\
\text { cenderung lebih } \\
\text { luwes, maka pendidik } \\
\text { tidak menekankan } \\
\text { siswa harus on kamera } \\
\text { saat nge-zoom. }\end{array}$ \\
\hline $\begin{array}{l}\text { Saat on kamera juga } \\
\text { peserta didik dalam } \\
\text { menerapkan } \\
\text { dekonstruktif } \\
\text { pendidikan tidak } \\
\text { dilakukan seperti } \\
\text { halnya pendidikan } \\
\text { tatap muka harus } \\
\text { menggunakan } \\
\text { seragam. Sehingga apa } \\
\text { yang dilakukan oleh } \\
\text { peserta didik bisa } \\
\text { dilakukan kapanpun } \\
\text { dan dimanapun. } \\
\text { Pelaksanaan } \\
\text { Dekontruksi } \\
\text { pendidikan di masa } \\
\text { pandemi saat } \\
\text { pelaksanaan } \\
\text { menerapkan strategi } \\
\text { yang tidak kaku } \\
\text { seperti halnya strategi } \\
\text { yang sangat } \\
\text { mendukung dalam } \\
\text { dekonstruksi } \\
\text { pendidikan. Strategi }\end{array}$ & $\begin{array}{l}\text { Saat on kamera juga } \\
\text { peserta didik dalam } \\
\text { menerapkan } \\
\text { dekonstruktif } \\
\text { pendidikan tidak } \\
\text { dilakukan seperti } \\
\text { halnya pendidikan } \\
\text { tatap muka harus } \\
\text { menggunakan } \\
\text { seragam. Sehingga apa } \\
\text { yang dilakukan oleh } \\
\text { peserta didik bisa } \\
\text { dilakukan kapanpun } \\
\text { dan dimanapun. } \\
\text { Pelaksanaan } \\
\text { Dekontruksi } \\
\text { pendidikan di masa } \\
\text { pandemi saat } \\
\text { pelaksanaan } \\
\text { menerapkan strategi } \\
\text { yang tidak kaku } \\
\text { seperti halnya strategi } \\
\text { yang sangat } \\
\text { mendukung dalam } \\
\text { dekonstruksi } \\
\text { pendidikan. Strategi } \\
\text { yang digunakan dalam } \\
\text { pembelajaran tentang }\end{array}$ & $\begin{array}{l}\text { Saat on kamera juga } \\
\text { peserta didik dalam } \\
\text { menerapkan } \\
\text { dekonstruktif } \\
\text { pendidikan tidak } \\
\text { dilakukan seperti } \\
\text { halnya pendidikan } \\
\text { tatap muka harus } \\
\text { menggunakan } \\
\text { seragam. Sehingga apa } \\
\text { yang dilakukan oleh } \\
\text { peserta didik bisa } \\
\text { dilakukan kapanpun } \\
\text { dan dimanapun. } \\
\text { Pelaksanaan } \\
\text { Dekontruksi } \\
\text { pendidikan di masa } \\
\text { pandemi saat } \\
\text { pelaksanaan } \\
\text { menerapkan strategi } \\
\text { yang tidak kaku } \\
\text { seperti halnya strategi } \\
\text { yang sangat } \\
\text { mendukung dalam } \\
\text { dekonstruksi } \\
\text { pendidikan. Strategi } \\
\text { yang digunakan dalam } \\
\text { pembelajaran tentang }\end{array}$ \\
\hline
\end{tabular}




\begin{tabular}{|l|l|l|}
\hline $\begin{array}{l}\text { akad adalah qishah, } \\
\text { mauidhatul hasanah, } \\
\text { open minded dan } \\
\text { demokeratif. }\end{array}$ & $\begin{array}{l}\text { akad adalah qishah, } \\
\text { mauidhatul hasanah, } \\
\text { open minded dan } \\
\text { demokeratif. }\end{array}$ & $\begin{array}{l}\text { akad adalah qishah, } \\
\text { mauidhatul hasanah, } \\
\text { open minded dan } \\
\text { demokeratif. }\end{array}$ \\
\hline
\end{tabular}

Pembelajaran Materi 2:

Materi Fikih Muamalat tentang Riba pada kelas A, B, dan C

\begin{tabular}{|c|c|c|}
\hline Kelas A & Kelas B & \\
\hline $\begin{array}{l}\text { Persiapan } \\
\text { Dalam penerapannya } \\
\text { proses pendidikan } \\
\text { dekonstruktif karena } \\
\text { cenderung lebih } \\
\text { luwes, maka pendidik } \\
\text { tidak menekankan } \\
\text { siswa harus on kamera } \\
\text { saat nge-zoom. }\end{array}$ & $\begin{array}{l}\text { Persiapan } \\
\text { Dalam penerapannya } \\
\text { proses pendidikan } \\
\text { dekonstruktif karena } \\
\text { cenderung lebih } \\
\text { luwes, maka pendidik } \\
\text { tidak menekankan } \\
\text { siswa harus on kamera }\end{array}$ & $\begin{array}{l}\text { Persiapan } \\
\text { Dalam penerapannya } \\
\text { proses pendidikan } \\
\text { dekonstruktif karena } \\
\text { cenderung lebih } \\
\text { luwes, maka pendidik } \\
\text { tidak menekankan } \\
\text { siswa harus on kamera } \\
\text { saat nge-zoom. }\end{array}$ \\
\hline $\begin{array}{l}\text { Saat on kamera juga } \\
\text { peserta didik dalam } \\
\text { menerapkan } \\
\text { dekonstruktif } \\
\text { pendidikan tidak } \\
\text { dilakukan seperti } \\
\text { halnya pendidikan } \\
\text { tatap muka harus } \\
\text { menggunakan } \\
\text { seragam. Sehingga apa } \\
\text { yang dilakukan oleh } \\
\text { peserta didik bisa } \\
\text { dilakukan kapanpun } \\
\text { dan dimanapun. } \\
\text { Pelaksanaan } \\
\text { Dekontruksi } \\
\text { pendidikan di masa } \\
\text { pandemi saat } \\
\text { pelaksanaan } \\
\text { menerapkan strategi } \\
\text { yang tidak kaku } \\
\text { seperti halnya strategi } \\
\text { yang sangat } \\
\text { mendukung dalam } \\
\text { dekonstruksi } \\
\text { pendidikan. Strategi }\end{array}$ & $\begin{array}{l}\text { Saat on kamera juga } \\
\text { peserta didik dalam } \\
\text { menerapkan } \\
\text { dekonstruktif } \\
\text { pendidikan tidak } \\
\text { dilakukan seperti } \\
\text { halnya pendidikan } \\
\text { tatap muka harus } \\
\text { menggunakan } \\
\text { seragam. Sehingga apa } \\
\text { yang dilakukan oleh } \\
\text { peserta didik bisa } \\
\text { dilakukan kapanpun } \\
\text { dan dimanapun. } \\
\text { Pelaksanaan } \\
\text { Dekontruksi } \\
\text { pendidikan di masa } \\
\text { pandemi saat } \\
\text { pelaksanaan } \\
\text { menerapkan strategi } \\
\text { yang tidak kaku } \\
\text { seperti halnya strategi } \\
\text { yang sangat } \\
\text { mendukung dalam } \\
\text { dekonstruksi } \\
\text { pendidikan. Strategi } \\
\text { yang digunakan dalam }\end{array}$ & $\begin{array}{l}\text { Saat on kamera juga } \\
\text { peserta didik dalam } \\
\text { menerapkan } \\
\text { dekonstruktif } \\
\text { pendidikan tidak } \\
\text { dilakukan seperti } \\
\text { halnya pendidikan } \\
\text { tatap muka harus } \\
\text { menggunakan } \\
\text { seragam. Sehingga apa } \\
\text { yang dilakukan oleh } \\
\text { peserta didik bisa } \\
\text { dilakukan kapanpun } \\
\text { dan dimanapun. } \\
\text { Pelaksanaan } \\
\text { Dekontruksi } \\
\text { pendidikan di masa } \\
\text { pandemi saat } \\
\text { pelaksanaan } \\
\text { menerapkan strategi } \\
\text { yang tidak kaku } \\
\text { seperti halnya strategi } \\
\text { yang sangat } \\
\text { mendukung dalam } \\
\text { dekonstruksi } \\
\text { pendidikan. Strategi } \\
\text { yang digunakan dalam }\end{array}$ \\
\hline
\end{tabular}




\begin{tabular}{|c|c|c|}
\hline $\begin{array}{l}\text { pembelajaran tentang } \\
\text { akad adalah qishah, } \\
\text { mauidhatul hasanah, } \\
\text { open minded dan } \\
\text { demokeratif. }\end{array}$ & $\begin{array}{l}\text { pembelajaran tentang } \\
\text { akad adalah qishah, } \\
\text { mauidhatul hasanah, } \\
\text { open minded dan } \\
\text { demokeratif. }\end{array}$ & $\begin{array}{l}\text { pembelajaran tentang } \\
\text { akad adalah qishah, } \\
\text { mauidhatul hasanah, } \\
\text { open minded dan } \\
\text { demokeratif. }\end{array}$ \\
\hline
\end{tabular}

\section{Dekonstruksi Materi Pendidikan}

Penerapan dalam dekonstruksi materi pendidikan membangun pola pikir peserta didik dari dalam. Strategi pembelajaran membentuk dekonstruksi secara luar tetapi materi pendidikan membentuk dekonstruksi dari dalam. Adanya dekonstruksi pendidikan ini sangat membantu open minded peserta didik dalam memahami materi. Materi yang diajarkan tidak seperti pola lama yang terstruktural, akan tetapi dalam dekonstruksi pendidikan ini logosentrisme tetap struktural tetapi juga memasukkan materi yang kontekstual sehingga materi itu berkembang sesuai zaman. Peneliti ketika memberikan materi pembelajaran mencoba memecah nilainilai isi materi sehingga peserta didik kritis dalam menanggapi materi yang disampaikan.

Materi pendidikan dekosntruktif pada materi akad dan riba seperti halnya:

1. Akad yang disampaikan secara teotitis adalah harus bertatap muka dan ada tempat pertemuan. Namun dibenturkan dengan kondisi sekarang sehingga akad tidak membutuhkan pertemuan tatap muka sekaligus tempat pertemuan. Kemudian peserta didik menanggapinya, pendidik disitu sebagai fasilitator.

2. Materi riba pada dasarnya ketika mengambil sebuah keuntungan yang nominalnya besar dibandingkan harga yang dibeli sebelumnya, maka ada keraguan riba disana. Kemudian kita benturkan juga denga bisnis online yang membelinya dengan harga relatif murah, kemudia menjualnya dengan harga yang pada umumnya di pasaran. Kemudian peserta didik disilahkan untuk menanggapinya dan pendidik sebagai fasilitatornya.

\section{Rekonstruksi}

Rekonstruksi pendidikan yang diungkapkan oleh Muhaimin, "ada beberapa yang harus ditingkatkan, dituju dalam pendidikan dalam kegiata pembelajaran yang meliputi: keimanan peserta didik, pemahaman atau penularan, penghayatan dan pengalaman."16 Dalm hal ini maka pendidikan walupun kompleks dalam permasalahannya namun bagaimana pendidikan tersebut direkonstruksi kembali dengan baik. Sehingga rekonstruksi penelitian ini lanjutan akibat perlakuan dekonstruktif sehingga pemahaman yang didapatkan tidak ngambang dan menemukan tujuan yang baik dan benar seperti halnya tujuan pendidikan.

\section{Rekonstruksi Proses Pendidikan}

Peneliti yang menjadi pendidik sekaligus menerapkan rekonstruksi proses pendidikan supaya peserta didi tidak menyepelhkan hal-hal yang itu sepeleh tetapi sebenarnya itu menjadi bagian penting dalam pendidikan. Namun dengan cara yang

${ }^{16}$ Muhaimin, Paradigma Pendidikan Islam Upaya Mengefektifkan Pendidikan Agama Islam di Sekolah, (Bandung: Rosdakarya, 2001), hal 78-79. 
luwes sebelumnya yaitu dekonstruktif bukan berati memangkas pendidikan haruis dilakukan secara kaku. Demikian proses pembelajaran yang dilakukan oleh peneliti sekaligu pendidik saat mengajar:

Pembelajaran Materi 1:

Materi Fikih Muamalat tentang Akad pada kelas A, B, dan C

\begin{tabular}{|c|c|c|}
\hline Kelas A & Kelas B & Kelas C \\
\hline $\begin{array}{l}\text { Persiapan } \\
\text { Dalam penerapannya } \\
\text { proses pendidikan } \\
\text { rekonstruktif lebih } \\
\text { cenderung kembali } \\
\text { pada sistem } \\
\text { pendidikan yang } \\
\text { sebenarnya, maka } \\
\text { dalam rekonstruksi } \\
\text { pendidikan ini peserta } \\
\text { didik setelah } \\
\text { didekonstruksi } \\
\text { kemudia } \\
\text { direkonstruksi } \\
\text { kembalii sehingga } \\
\text { tidak menyepelehkan } \\
\text { hal-halyang } \\
\text { sebelumnya tadi. } \\
\text { Seperti halnya dalam } \\
\text { mengajar pendidikan } \\
\text { menjelaskan kembali } \\
\text { dan menasehati } \\
\text { dengan baik kepada } \\
\text { peserta didik bagi } \\
\text { yang tidak memiliki } \\
\text { kesibuka seharusnya } \\
\text { on camera, bagi yang } \\
\text { tidak ada acara juga } \\
\text { bisa menggunakan } \\
\text { pakaian yang rapi } \\
\text { walaupun tidak } \\
\text { seragam. Sehingga } \\
\text { nasihat ini bisa } \\
\text { menjadi alternatif dan } \\
\text { solusi atau } \\
\text { pemakluman dalam } \\
\text { pendidikan saat } \\
\text { pandemi dengan tidak }\end{array}$ & $\begin{array}{l}\text { Persiapan } \\
\text { Dalam penerapannya } \\
\text { proses pendidikan } \\
\text { rekonstruktif lebih } \\
\text { cenderung kembali } \\
\text { pada sistem } \\
\text { pendidikan yang } \\
\text { sebenarnya, maka } \\
\text { dalam rekonstruksi } \\
\text { pendidikan ini peserta } \\
\text { didik setelah } \\
\text { didekonstruksi } \\
\text { kemudia } \\
\text { direkonstruksi } \\
\text { kembalii sehingga } \\
\text { tidak menyepelehkan } \\
\text { hal-halyang } \\
\text { sebelumnya tadi. } \\
\text { Seperti halnya dalam } \\
\text { mengajar pendidikan } \\
\text { menjelaskan kembali } \\
\text { dan menasehati } \\
\text { dengan baik kepada } \\
\text { peserta didik bagi } \\
\text { yang tidak memiliki } \\
\text { kesibuka seharusnya } \\
\text { on camera, bagi yang } \\
\text { tidak ada acara juga } \\
\text { bisa menggunakan } \\
\text { pakaian yang rapi } \\
\text { walaupun tidak } \\
\text { seragam. Sehingga } \\
\text { nasihat ini bisa } \\
\text { menjadi alternatif dan } \\
\text { solusi atau } \\
\text { pemakluman dalam } \\
\text { pendidikan saat } \\
\text { pandemi dengan tidak }\end{array}$ & $\begin{array}{l}\text { Persiapan } \\
\text { Dalam penerapannya } \\
\text { proses pendidikan } \\
\text { rekonstruktif lebih } \\
\text { cenderung kembali } \\
\text { pada sistem } \\
\text { pendidikan yang } \\
\text { sebenarnya, maka } \\
\text { dalam rekonstruksi } \\
\text { pendidikan ini peserta } \\
\text { didik setelah } \\
\text { didekonstruksi } \\
\text { kemudia } \\
\text { direkonstruksi } \\
\text { kembalii sehingga } \\
\text { tidak menyepelehkan } \\
\text { hal-halyang } \\
\text { sebelumnya tadi. } \\
\text { Seperti halnya dalam } \\
\text { mengajar pendidikan } \\
\text { menjelaskan kembali } \\
\text { dan menasehati } \\
\text { dengan baik kepada } \\
\text { peserta didik bagi } \\
\text { yang tidak memiliki } \\
\text { kesibuka seharusnya } \\
\text { on camera, bagi yang } \\
\text { tidak ada acara juga } \\
\text { bisa menggunakan } \\
\text { pakaian yang rapi } \\
\text { walaupun tidak } \\
\text { seragam. Sehingga } \\
\text { nasihat ini bisa } \\
\text { menjadi alternatif dan } \\
\text { solusi atau } \\
\text { pemakluman dalam } \\
\text { pendidikan saat } \\
\text { pandemi dengan tidak }\end{array}$ \\
\hline
\end{tabular}




\begin{tabular}{|l|l|l|}
\hline $\begin{array}{l}\text { menghilangkan nilai } \\
\text { ketertiban dan }\end{array}$ & $\begin{array}{l}\text { menghilangkan nilai } \\
\text { kedisiplinan }\end{array}$ & $\begin{array}{l}\text { menghilangkan nilai } \\
\text { ketertiban dan }\end{array}$ \\
Pelaksanaan & kedisiplinan & kedisiplinan \\
Rekonstruksi & Pelaksanaan & Pelaksanaan \\
pendidikan dalam & Rekonstruksi & Rekonstruksi \\
penerapannya & pendidikan dalam & pendidikan dalam \\
pendidik & penerapannya & penerapannya \\
menggunakan strategi & pendidik & pendidik \\
uswah. sehingga & menggunakan strategi & menggunakan strategi \\
peserta didik bisa & uswah. sehingga & uswah. sehingga \\
memahami nasihat & peserta didik bisa & peserta didik bisa \\
sebenarnya dalam & memahami nasihat & memahami nasihat \\
pendidikan bahwa apa & sebenarnya dalam & sebenarnya dalam \\
yang menjadi nilai & pendidikan bahwa apa & pendidikan bahwa apa \\
pendidikan itu dalam & yang menjadi nilai & yang menjadi nilai \\
pembentukan & pendidikan itu dalam & pendidikan itu dalam \\
karakter. & pembentukan & pembentukan \\
\hline
\end{tabular}

Pembelajaran Materi 2:

Materi Fikih Muamalat tentang Riba pada kelas A, B, dan C

\begin{tabular}{|c|c|c|}
\hline Kelas A & Kelas B & Kelas C \\
\hline $\begin{array}{l}\text { - } \\
\text { Persiapan } \\
\text { Dalam penerapannya } \\
\text { proses pendidikan } \\
\text { rekonstruktif lebih } \\
\text { cenderung kembali } \\
\text { pada sistem } \\
\text { pendidikan yang } \\
\text { sebenarnya, maka } \\
\text { dalam rekonstruksi } \\
\text { pendidikan ini peserta } \\
\text { didik setelah } \\
\text { didekonstruksi } \\
\text { kemudia } \\
\text { direkonstruksi } \\
\text { kembalii sehingga } \\
\text { tidak menyepelehkan } \\
\text { hal-halyang } \\
\text { sebelumnya tadi. }\end{array}$ & $\begin{array}{l}\text { - } \\
\text { Persiapan } \\
\text { Dalam penerapannya } \\
\text { proses pendidikan } \\
\text { rekonstruktif lebih } \\
\text { cenderung kembali } \\
\text { pada sistem } \\
\text { pendidikan yang } \\
\text { sebenarnya, maka } \\
\text { dalam rekonstruksi } \\
\text { pendidikan ini peserta } \\
\text { didik setelah } \\
\text { didekonstruksi } \\
\text { kemudia } \\
\text { direkonstruksi } \\
\text { kembalii sehingga } \\
\text { tidak menyepelehkan } \\
\text { hal-halyang } \\
\text { sebelumnya tadi. }\end{array}$ & $\begin{array}{l}\text { Persiapan } \\
\text { Dalam penerapannya } \\
\text { proses pendidikan } \\
\text { rekonstruktif lebih } \\
\text { cenderung kembali } \\
\text { pada sistem } \\
\text { pendidikan yang } \\
\text { sebenarnya, maka } \\
\text { dalam rekonstruksi } \\
\text { pendidikan ini peserta } \\
\text { didik setelah } \\
\text { didekonstruksi } \\
\text { kemudia } \\
\text { direkonstruksi } \\
\text { kembalii sehingga } \\
\text { tidak menyepelehkan } \\
\text { hal-halyang } \\
\text { sebelumnya tadi. }\end{array}$ \\
\hline $\begin{array}{l}\text { Seperti halnya dalam } \\
\text { mengajar pendidikan } \\
\text { menjelaskan kembali } \\
\text { dan menasehati }\end{array}$ & $\begin{array}{l}\text { Seperti halnya dalam } \\
\text { mengajar pendidikan } \\
\text { menjelaskan kembali } \\
\text { dan menasehati }\end{array}$ & $\begin{array}{l}\text { Seperti halnya dalam } \\
\text { mengajar pendidikan } \\
\text { menjelaskan kembali } \\
\text { dan menasehati }\end{array}$ \\
\hline
\end{tabular}




\begin{tabular}{|l|l|l|}
\hline dengan baik kepada & dengan baik kepada & dengan baik kepada \\
peserta didik bagi & peserta didik bagi & peserta didik bagi \\
yang tidak memiliki & yang tidak memiliki & yang tidak memiliki \\
kesibuka seharusnya & kesibuka seharusnya & kesibuka seharusnya \\
on camera, bagi yang & on camera, bagi yang & on camera, bagi yang \\
tidak ada acara juga & tidak ada acara juga & tidak ada acara juga \\
bisa menggunakan & bisa menggunakan & bisa menggunakan \\
pakaian yang rapi & pakaian yang rapi & pakaian yang rapi \\
walaupun tidak & walaupun tidak & walaupun tidak \\
seragam. Sehingga & seragam. Sehingga & seragam. Sehingga \\
nasihat ini bisa & nasihat ini bisa & nasihat ini bisa \\
menjadi alternatif dan & menjadi alternatif dan & menjadi alternatif dan \\
solusi atau & solusi atau & solusi atau \\
pemakluman dalam & pemakluman dalam & pemakluman dalam \\
pendidikan saat & pendidikan saat & pendidikan saat \\
pandemi dengan tidak & pandemi dengan tidak & pandemi dengan tidak \\
menghilangkan nilai & menghilangkan nilai & menghilangkan nilai \\
ketertiban dan & ketertiban dan & ketertiban dan \\
kedisiplinan & kedisiplinan & kedisiplinan \\
Pelaksanaan & Pelaksanaan & Pelaksanaan \\
Rekonstruksi & Rekonstruksi & Rekonstruksi \\
pendidikan dalam & pendidikan dalam & pendidikan dalam \\
penerapannya & penerapannya & penerapannya \\
pendidik & pendidik & pendidik \\
menggunakan strategi & menggunakan strategi & menggunakan strategi \\
uswah. sehingga & uswah. sehingga & uswah. sehingga \\
peserta didik bisa & peserta didik bisa & peserta didik bisa \\
memahami nasihat & memahami nasihat & memahami nasihat \\
sebenarnya dalam & sebenarnya dalam & sebenarnya dalam \\
pendidikan bahwa apa & pendidikan bahwa apa & pendidikan bahwa apa \\
yang menjadi nilai & yang menjadi nilai & yang menjadi nilai \\
pendidikan itu dalam & pendidikan itu dalam & pendidikan itu dalam \\
pembentukan & pembentukan & pembentukan \\
karakter. & karakter. & karakter. \\
\hline
\end{tabular}

\section{Rekonstruksi Materi Pendidikan}

Rekontruksi materi pendidikan yang diterapkan adalah mengembalikan apa yang sudah direkonstruksi sehingga kembali kepada substansi. Materi pendidikan rekonstruktif pada materi akad dan riba seperti halnya:

1. Setelah materi akad didekonstruksi baik dari pendekatan bahasa, budaya, dan filsafat. Maka kembali kepada teoritis bahwan rekonstruksi mampu 
memberikan materi akad secara utuh. Sehingga apa yang dipahami oleh peserta didik tidak kontra atau bertabrakan dengan teori sebelumnya.

2. Setelah materi riba didekonstruksi baik dari pendekatan bahasa, budaya, dan filsafat. Maka kembali kepada teoritis bahwan rekonstruksi mampu memberikan materi riba secara utuh. Sehingga apa yang dipahami oleh peserta didik tidak kontra atau bertabrakan dengan teori sebelumnya.

\section{Pendidikan Karakter}

Pendidikan yang diidentikan dengan karakter selain dibentuk dalam pembinaan karakter secara formal dalam pendidika. Namun pendidikan karakter diarahkan kepada pembangunan bangsa secara menanamkan nilai-nilai moral bangsa. Adapun nilai pembangunan karakter bangsa sebagai berikut: ${ }^{17}$

\begin{tabular}{|c|c|}
\hline Taqwa & $\begin{array}{l}\text { 1. Mengucapkan doa setiap memulai dan mengakhiri suatu pekerjaan. } \\
\text { 2. Bersyukur atas setiap nikmat yang diberikan Allah } \\
\text { 3. Mengerjakan setiap perintah agama dan menjauhi larangan-Nya } \\
\text { 4. Menyesal setiap membuat kesalahan dan segera mohon ampun kepada } \\
\text { Tuhan }\end{array}$ \\
\hline Jujur & $\begin{array}{l}\text { 1. Berkata benar (tidak bohong) } \\
\text { 2. Berbuat sesuai aturan (tidak curang). } \\
\text { 3. Menepati janji yang diucapkan. } \\
\text { 4. Bersedia menerima sesuatu atas dasar hak } \\
\text { 5. Menolak sesuatu pemberian yang bukan haknya } \\
\text { 6. Berpihak pada kebenaran. } \\
\text { 7. Meletakkan sesuatu pada tempatnya. } \\
\text { 8. Dapat menyimpan rahasia }\end{array}$ \\
\hline Disiplin & $\begin{array}{l}\text { 1. Patuh pada setiap peraturan yang berlaku } \\
\text { 2. Patuh pada etika sosial/masyarakat setempat } \\
\text { 3. Menolak setiap ajakan untuk melanggar hokum } \\
\text { 4. Dapat mengendalikan din terhadap perbuatan tercela } \\
\text { 5. Hemat dalam menggunakan uang dan barang } \\
\text { 6. Menyelesaikan tugas tepat waktu. } \\
\text { 7. Meletakkan sesuatu pada tempatnya } \\
\text { 8. Dapat menyimpan rahasia. }\end{array}$ \\
\hline Demokratis & $\begin{array}{l}\text { 1. Bersedia mendengarkan pendapat orang lain. } \\
\text { 2. Menghargai perbedaan pendapat. } \\
\text { 3. Tidak memaksakan kehendak kepada orang lain. } \\
\text { 4. Toleran dalam bermusyawarab diskusi. } \\
\text { 5. Bersedia melaksanakan setiap hasil keputusan secara bersama } \\
\text { 6. Menghargai kritikan yang dilontarkan orang lain } \\
\text { 7. Membuat keputusan yang adil. }\end{array}$ \\
\hline
\end{tabular}




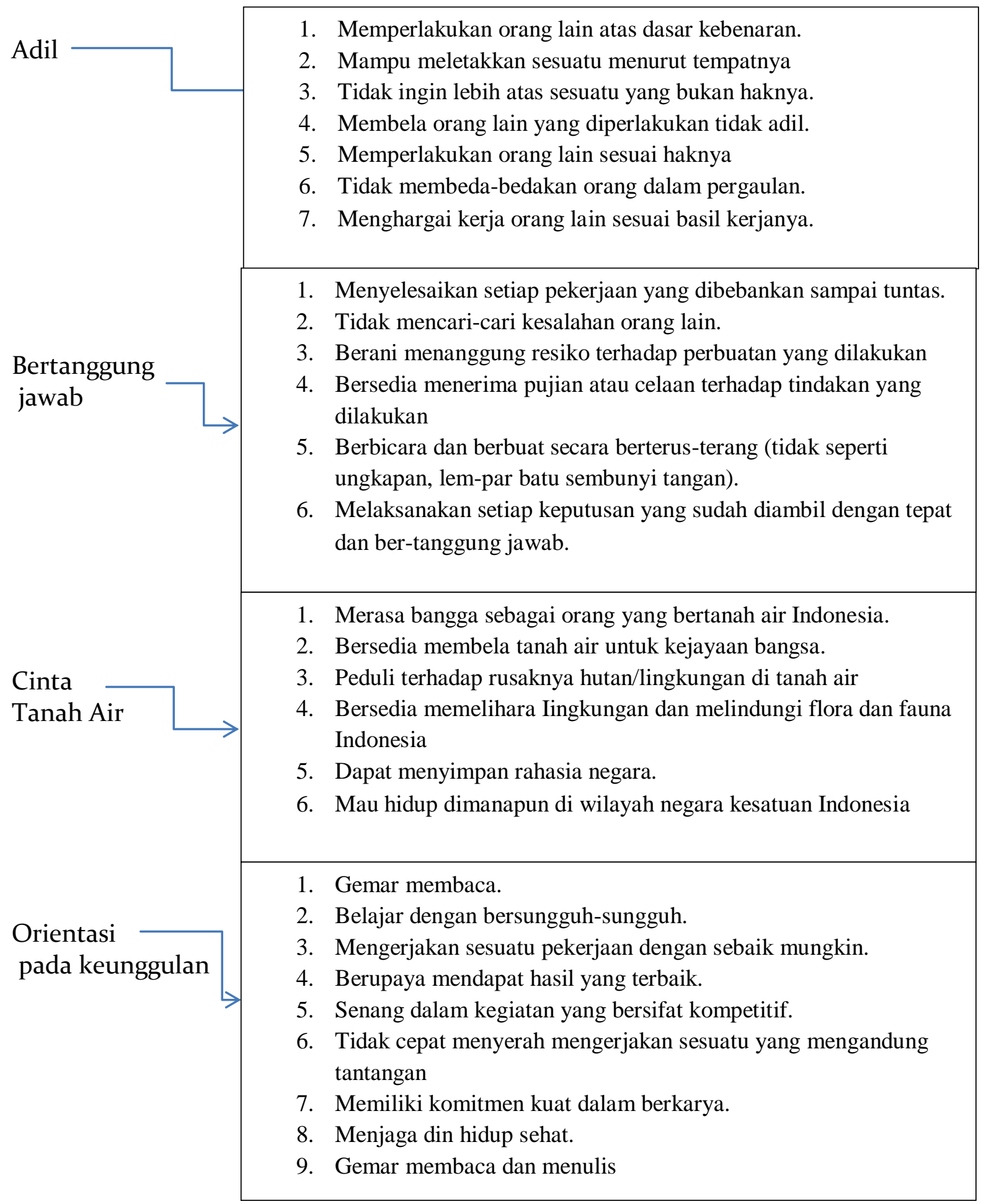




Gotong $\quad \begin{array}{ll}\text { 1. } & \text { Memahami bahwa kerjasama merupakan kekuatan. } \\ \text { 2. } & \text { Memahami hasil kerjasama adalah untuk kebaikan bersama. } \\ \text { 3. } & \text { Dapat menyumbangkan pikiran dan tenaga untuk kepentingan } \\ \text { bersama. } \\ \text { 4. }\end{array}$

\section{Simpulan}

Bahwasannya dalam menerapkan pendidikan baik tatap muka dan daring sebenarnya tergantung aktifis pendidikan. Namun harus ditekankan kembali bahwa model atau startegi yang baik akan menciptakan pendidikan yang baik pula. Karena masa pandemi ini yang cenderung sulit menentukan pola komunikasi pendidikan baik dari proses pendidikan dan materi pendidikan. Maka menjadi penting dekonstruksi dan rekonstruksi pendidikan di masa pandemi ini.

Proses pendidikan dekontruksi pada proses pendidikan dilakukan dengan mengajak komunikasi, memasifkan tanya jawab antar peserta didik dengan peserta didik, sekaligus peserta didik dengan pendidik. Ketika kamera dimatikan, maka pertanyaan pertanyaan ituditanyakan satu persatu sambil mengabsen peserta didik. Sehingga pendidik mengetahui mana peserta didik yang belajar sungguhan dan tidak. Tidak hanya sekedar itu dalam dekonstruksi proses pendidikan peserta didik dan peserta didik bisa saling bertukar gagasan. Pendekatan yang dilakukan dalam menerapkan proses pendidikan dekonstruksi yaitu antropologi dan sosiologi. Bisa melihat bagiamana barat bisa lebihmaju dibandingkan indonesia saat ini yang harus mengikuti serba peraturan. Hasil dari keaktifan peserta didik di kelas A, B dan C. Kelas A yang bertanya kepada pendidikan 4 orang, peserta didik yang menanggapi ada 5 orang sehingga junlah peserta didik yang aktif 9 orang dari 40 mahasiswa. Kelas $\mathrm{B}$ yang bertanya 5orang dan yang menanggapi 8 orang, jumlah peserta didik yang aktif 13 mahasiswa. Kelas $C$ yang bertanya 3 orang dan yang memamggapi 8 orang, jumlah mahasiswa yang aktif 11 orang.

Materi pendidikan dekontruksi menciptakan suatu persoalan persoalan baru sehingga sangat mendukung dalm tanya jawab. Sesuatu hal yang harus dipikirkan 
dari hal yang kecil bisa terpikirkan. Pendekatan yang dilakukan adalah pendekatan filsafat sehingga bisa membuka pikiran peserta didik (open minded). Kenyataannya dalam materi pendidikan tidak bisa mnjadi doktrin kebenaran, karena pengetahuan itu berkembang. Ketika pikiran itu logis dan ada dasarnya maka boleh dilakukan secara ilmiah. Sementara rekonstruksi pendidikan baik dari proses dan materi pendidikan memberikan ruh kembali kepada pendidika yang sesuai dengan teori. Maka tidak menghilangkan nilai-nilai pendidikan, namun dalam penerapannya disisihkan terlebih dahulu dalam artian tidak dilakukan secara ajek dan paten. Namun memberikan peluang kepada praktisis pendidikan untuk modifikasi supaya tidak membatasi proses pendidikan sekaligus materi pendidikan.

Pendidikan karakter yang didapatkan dari kelas A, B, dan C mencakup 75\% terpenuhi dengah diterapkan model dekonstruksi dan rekonstruksi dalam pembelajaran. Hal ini terbukti ketika peserta didik melakukan kejujuran seperti berkata dengan benar baik secara teoritis dan keadaan yang dialami, disiplin dalam artian walaupun siswa tidak memakai seragam atau on camera seperti halnya masuk walaupun mematikan kamera teapi aktif dalam diskusi karena peserta didik ketika posisi di rumah selain statusnya sebagai mahasiswa tetapi juga sebagai anak dan masyarakat. adapun juga yang dihasilkan dalam pendidikan karakter peserta didik lebih demokeratis artinya menghargai pendapat orang lain, menerima kritikan dan bersedia menerima keputusan yang dibuat bersama.

Nilai yang ada dalam pendidikan karakter juga bersifat adil, peserta didik juga mampu melaksanakan tidak menjawab atau memotong pembicaraan teman lainnya ketika berbicara. Selain itu cinta tanah air peserta didik memiliki rasa kepedulian atau ketertarikan untuk membahas apa yang terjadi di negara ini. Kemudia dalam pendidikan karakter hail dari dekonstruksi dan rekonstruksi yaitu berorientasi pada keunggulan, gotong royong dan saling menghargai satu sama lain. Menempatkan nilai-nilai yang ada dalam pendidikan karakter akibat pembelajaran dekonstruksi dan rekonstruksi tidak bisa dipahami secara paten harus memenuhi semua. Akan tetapi ketika ada salah satu sikap yang masuk dalam kategori nilai tersebut bahwa peserta didik itu sudah melakukan bagian dari nilai-nilai tersebut. sehingga singkat penjelasan bahwa dekonstruksi dan rekonstuksi ini menjadikan peserta didik kebanyakan memenuhi nilai-nilai tersebut dari 11 nilai memenuhi 10 nilai. Tetapi dari 76 point yang terkandung 10 nilai tersebut 50 point lebih terpenuhi.

Penelitian ini semoga bermanfaat bagi aktifis pendidikan sehingga bisa memformulasikan sistem pendidikan di masa pandemi ini. Selain itu penelitian ini semoga bermanfaat bagi peeliti yang merujuk terhadap dekonsrtuksi dan rekonstruksi dalam hal apapun lebih khususnya kepada pendidikan karakter. 


\section{DAFTAR PUSTAKA}

Abu Ahmadi dan Joko Tri Prasetyo, 1997. Strategi Belajar Mengajar Bandung: Pustaka Setia.

Amin Abdullah, 2001. "Problem Epistemologis-Metodologis Pendidikan Agama", dalam Munir Mulkhan, dkk, Relpnstruksi Pendidikan dan Tradisi Pesantren, Religiusitas Iptek, Yogyakarta: Pustaka Pelajar.

Dirgantoro, Crown, 2001. Manajemen Strategi; Konsep dan Kasus Implementasi,(Jakarta: Grafindo Persada.

Hisyam Zaini dkk, 2008. Strategi Pembelajaran Aktif, Yogyakarta: Pustaka Insani Madani.

Kirschenbaum, Howard. 200o. From Va-lues Clarification to Character Educa-tion: A Personal Journey." The Journal of Humanistic Counseling, Education and Development. Vol. 39, No. 1.

J.R.S. Adisusilo,. 2012. Pembelajaran Nilai Ka-rakter. Jakarta: PT. Raja Grafindo Persada.

J.Van Baal, Sejarah dan Pertumbuhan Teori antropologi Budaya, jilid 2 pengantar Selo Soemardjan.

Johnson, Louarne, 2008. Pengajaran yang Kreatif, Indeks.

Lumongga Lubis Namora, 2011. Memahami Dasar-Dasar Konseling DalamTeori DanPraktik,Jakarta: Kencana Prenada Media Grup.

Muhaimin, 2001. Paradigma Pendidikan Islam Upaya Mengefektifkan Pendidikan Agama Islam di Sekolah, Bandung: Rosdakarya.

Muslih Usa dan Aden Wijaya, 1987. Pendidikan Islam dalam Peradaban Industrial Yogyakarta: Aditia Media.

Ritzer, George. 2012 Teori Sosiologi Klasik Sampai Perkembangan Terakhir Postmodern, Yogyakrta: Pustaka Pelajar.

Sanjaya, Wina. 2010. Strategi Pembelajaran Berorientasi Standart Proses Pendidikan. Jakarta:Prenada.

Setiawan, Deny. 2013. Peran Pendidikan Karakter Dalam Mengembangkan Kecerdasan Moral, Jurnal Pendidikan Karakter,Tahun III, Nomorı.

Sugiyono, 2013. Metode Penelitian Pendidikan (Pendekatan Kuantitatif, Kualitatif, dan RED), Bandung: Alfabet.

Sukmadinata, Nana Syaodih, 2013. Metode Penelitian Pendidikan, Bandung: Remaja Rosdakarya. 